\title{
Response and Behavior of Rajungan Portunus pelagicus on the Use of Natural Bait and Artificial Bait PVa Chamois
}

\author{
Arizal Pratama ${ }^{1}$, Musbir $^{2}$, Andi Assir Marimba ${ }^{3}$ \\ ${ }^{1}$ Magister Program of Fisheries Science, Hasanuddin University, Makassar - South Sulawesi \\ ${ }^{2,3} \mathrm{M}$ arine Science and Fisheries Faculty of Hasanuddin University, Makassar- South Sulawesi
}

\begin{abstract}
Rajungan ( Portunus pelagicus) is one of the fisheries resources that has important economic value as an export commodity. The exploitation of rajungan is done by using traps. The success of catching using traps is influenced by several factors such as traps construction, soaking time and bait, the research method uses experimental methods. This study aims to determine the comparison of responses and behavior of rajungan to natural bait and artificial bait. Two types ofbait used are sardinella fish meat ( sardinella fimbriata) and Pva Chamois. The measured time data was collected by testing the habits and speed of 10 rajungan samples in response to bait and data analysis based on the t-test using the independent t-test at 4 phases of chemical stimulation. Selain carried out a descriptive analysis of the pattern of rajungan movements in response to the bait given, the results of the analysis showed that 3 phases of rajungan behavior, namely detection, orientation, and locomotive, did not have a significant difference, whereas in the feeding initiation phase there were significant differences. Furthermore, the movement pattern shown by the rajungan in response to natural bait is a direct movement pattern while the artificial bait is a non-direct movement pattern.

Keywords-Artificial lure, behavior, motion patterns. natural bait, rajungan
\end{abstract}

\section{INTRODUCTION}

Rajungan ( Portunus pelagicus ) is one of the fisheries resources that has important economic value as an export commodity. Fresh and processed rajungan exports to various countries, including Singapore, Hong Kong, Japan, Malaysia, Taiwan, and the United States. The high market demand and prices of rajungan can increase the income of fishermen (Adam. 2006). Market demand and high prices cause the capture of natural rajungan to increase or fishermen catch large numbers of rajungan. This is because the rajungan fishery resources are open access (open access), similar to other fishery resources in Indonesia.

In open exploitation, fishermen are competing to increase the effort, even making arrests to the catchment area further from their base (Adam. 2006). In addition, national rajungan products are obtained by cultivation and capture. Catching rajungan directly from nature is done by using various types of traps and one of them is traps (Rakhmadevi, 2004).

The success of catching using traps is influenced by several factors such as bubbling construction, soaking time and bait (Miller, 1990). Bait is one of the important factors in supporting the success of a fishing operation, especially for passive fishing gear such as traps and fishing rods (Subani and Barus 1989).

Traps fishing gear usually uses natural bait in the form of fish, because it is easily obtained and still has good freshness (Ramdani, 2007). There are various types of bait used in fishing activities, including natural and artificial bait. As for the traps fishing gear which is operated to catch the rajungan, it usually uses natural bait in the form of sardinella fish (Sardinella fimbriata). sardinella fish is widely used because it has good freshness.

The problem that is often faced by passive fishing devices, including Traps, is that the operation of these fishing gear requires bait. The availability of bait sometimes does not always exist so that it affects the intensity of the catch that cannot be done at any time. On the other hand, baitfish have a relatively high price so that it will cause the operational costs of catching fish traps to be higher. Therefore, the need to make artificial bait that is cheap has a specific odor and is always available so that the results are expected to be more effective than the bait that has been used by fishermen so that the productivity of fishing can increase. 


\section{THE RESEARCH METHOD}

Research was conducted in 2 Months (January 2019 February 2019), in the Bonto Ujung Village, Tarowang Subdistrict, Jeneponto Regency, South Sulawesi The selection of the research location was determined based on the habit of using traps fishing gear by local fishermen and the experimental laboratory was carried out as close as possible to the fishing location to maintain the parameters and suitability of aquarium conditions and fishing .

This research was carried out by following an experimental method, namely an experimental design that was tested to obtain information about the problem being studied. Through this method, information is needed in conducting research about the issues to be discussed so that a conclusion will be produced in accordance with the objectives of the study (Sudjana, 1994).

The research method used is an experimental laboratory method. The sample used as an object is carapace-sized rajungan> $9.5 \mathrm{~cm}$ using bait song. The research was carried out based on previous research by Supadminingsih (2015), Fitri (2016), and Asryanto (2016) which had been refined so that the research was carried out as follows:

1. Maintenance phase

The maintenance stage is the stage of adaptation of the rajungan Portunus pelagicus in laboratory conditions for 2 days. Rajungan not given food and left to dwell in a bag net and tied up against seaweed

2. Treatment preparation stages
Data collection by observing. Primary data taken in the form of observing the pattern of rajungan movements done after the rajungan passing through the arousal area until it enters the food area and the crunch response time for the type of food as from the time it is inserted into the treatment aquarium as the barrier is opened to the rajungan enters the catchable area. Observations made in the area of start, searching and finding are in the form of:

a. Detection and Orientation

Is the phase that occurs in the start area, namely the rajungan Portunus pelagicus is said to be aroused when the bulkhead is opened, the measurement of the speed of the rajungan movement use stopwatch done The start area is used as area A with a width of $35 \mathrm{~cm}$ considering the size of the rajungan with a carapace of $11 \mathrm{~cm}$ has a large and wide size, and this applies to (finding);

\section{b. Locomotion}

Rajungan perform a search for signal sources in the searching area and observe the pattern of rajungan movement in looking for food to enter the catchable area and finding the area. The size of this area is $70 \mathrm{~cm}$ long considering the ease of unit in speed;

c. Initiation of Feeding (finding food)

It is an area of food if the rajungan has entered the catchable area, it is said to be a rajungan respond to the smell of food. Measuring the speed of the rajungan movement use the stopwatch stops. Then the rajungan response was observed food after the rajungan Portunus pelagicus enters cachable area and found the food (finding). Repetition is calculated for each rajungan group for each food. Next design Aquarium Treatment:.

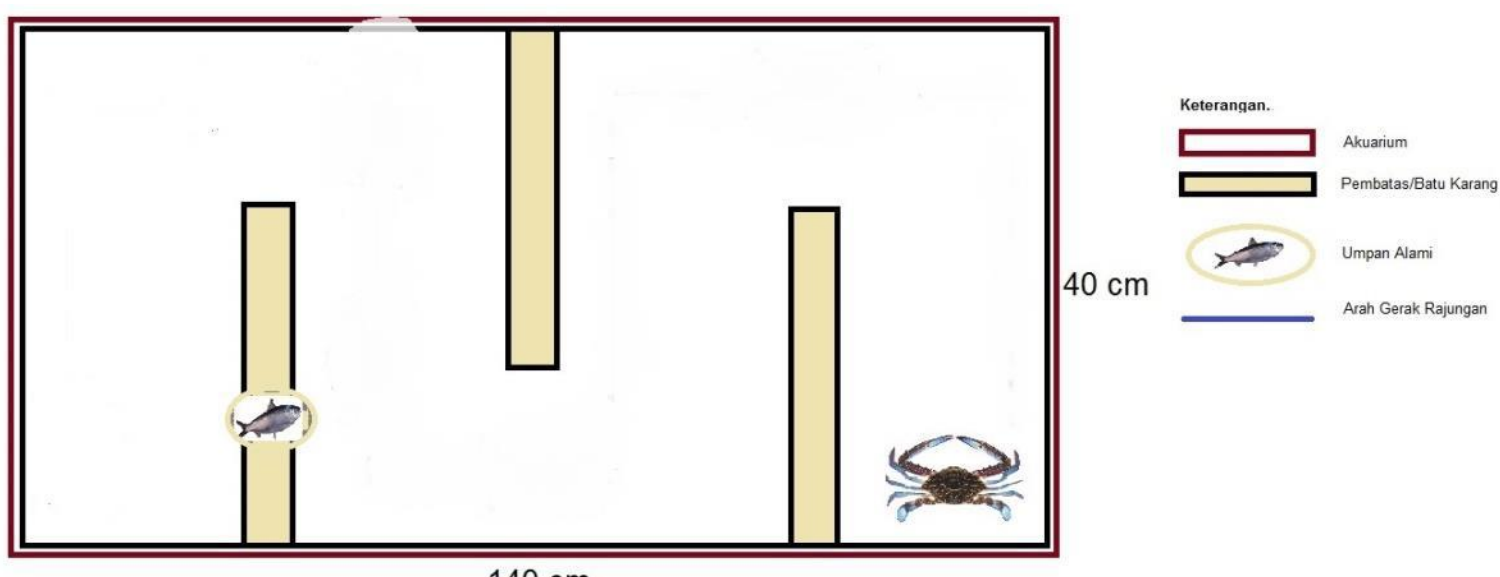

$140 \mathrm{~cm}$

Fig.1: Design of the rajungan response study natural bait 


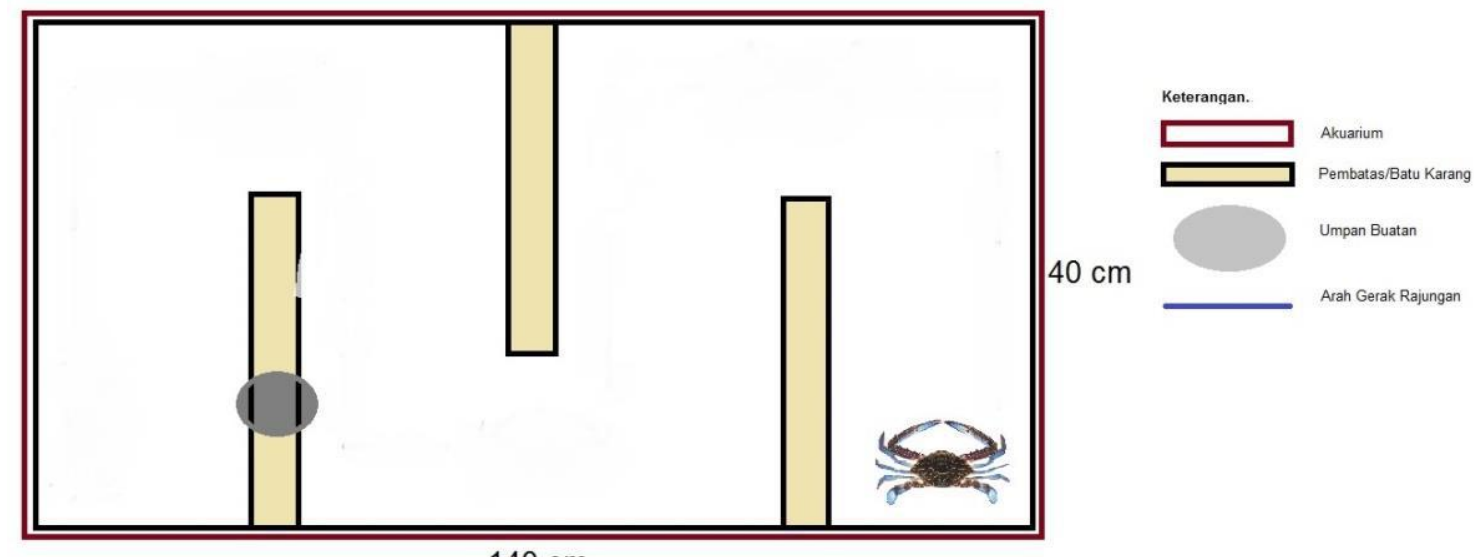

$140 \mathrm{~cm}$

Fig.2: Design of rajungan response research artificial bait

The treatment limit is made one hour, this is related to the rate of release of amino acids in proteins in seawater which will decrease after 1-hour immersion. According to Perdian, (2014), the rate of release of amino acids in tembang fish is high at the time of immersion in the first hour and then decreases with increasing duration of immersion.

Data obtained from the observation processed and compiled in the table, then do data processing in order to be concluded in accordance with the purposes of research. Data analysis will be carried out as follows:

Raw data that has been collected needs to be labeled in groups and categorization is held, so that the data has meaning to answer the problem and is useful in testing hypotheses (Natsir, 2003). Data normality testers aim to find out whether the distribution of this data is normal or not, after which a variance test with a normality test can also be examined by the Kolmogorov-Smirnov test. If the distribution data is normal, then it is analyzed using an independent t-test

\section{RESULTS}

The Observations were made on 10 rajungan with 2 different feed-giving treatments with adult age stages in accordance with the catch target which was the objectives of this study.

Descriptive data produced showed male rajungan had a larger carapace size and longer claws compared to female rajungan. The carapace color of the male rajungan is bluish with bright white patches, while the female has a greenish carapace color with gloomy white patches. Color differences are seen in individuals who are rather large even though they are not yet mature. The carapace length of this animal can reach $10.8-13.1 \mathrm{~cm}$.

The average time needed for rajungan to respond to chemical stimuli from natural feed sources can be distinguished based on the stimulation phase and the movements carried out are described as follows:

Table 1. Time and behavior of rajungan responding to natural bait

\begin{tabular}{|c|c|c|c|c|}
\hline Portunu & & & ne $(s)$ & \\
\hline $\begin{array}{l}\text { p } \\
\text { pelagicu } \\
S\end{array}$ & Detection & $\begin{array}{l}\text { Orientatio } \\
n\end{array}$ & $\begin{array}{l}\text { Locomotio } \\
n\end{array}$ & $\begin{array}{l}\text { Initiatio } \\
n \quad \text { of } \\
\text { Feeding }\end{array}$ \\
\hline I.a & 2520 & 42 & 148 & 20 \\
\hline I.b & 1260 & 20 & 120 & 10 \\
\hline I.c & 2100 & 45 & 180 & 18 \\
\hline I.d & 660 & 30 & 180 & 18 \\
\hline I.e & 2400 & 15 & 122 & 10 \\
\hline
\end{tabular}

Table 2. Time and behavior of rajungan responding to artificial bait

\begin{tabular}{|c|c|c|c|c|}
\hline Portunu & & & $n e(s)$ & \\
\hline $\begin{array}{l}\text { s } \\
\text { pelagic } \\
\text { us }\end{array}$ & Detection & $\begin{array}{l}\text { Orientatio } \\
n\end{array}$ & $\begin{array}{l}\text { Locomotio } \\
n\end{array}$ & $\begin{array}{l}\text { Initiation } \\
\text { Of } \\
\text { Feeding }\end{array}$ \\
\hline II.a & 3300 & 30 & 162 & 60 \\
\hline II.b & 3150 & 45 & 240 & 90 \\
\hline II.c & 1530 & 20 & 180 & 60 \\
\hline II.d & 1890 & 30 & 180 & 60 \\
\hline II.e & 3600 & 30 & 140 & 90 \\
\hline
\end{tabular}

The use of artificial bait in five rajungan samples shows the response and behavior of rajungan divided into 4 phases based on chemical stimuli by looking at the indicators and movements of sensory organs and the main movements towards food sources

In the four phases of rajungan behavior on natural bait, it can be concluded that the time needed by the rajungan to detect the highest chemical stimuli is in the first phase 
(Detection). This is in accordance with the study (Supadminingsih, 2015) arousal to wait and be careful, in response to food.

In the four phases of rajungan behavior on artificial bait can be concluded that the time needed for rajungan to detect the highest chemical stimuli is in the first phase (Detection), when compared to using natural bait which tends to be stimulated faster by rajungan organs this is caused by bait naturally fulfilling the requirements to stimulate the sense of smell and taste. The odor dissolved in water using natural bait stimulates receptors on the olfactory organs which are part of the fish's sense of smell and the type of rajungan (Ramdhani, 2007).

\section{Detection}

In observation of behavior navigating bridge in the early phase of this shows that the rajungan are aware of the presence of odors generated by both natural bait or artificial bait.

Table 3. Detection phase t-test

\begin{tabular}{|lll|l|r|r|r|}
\hline & & F & Sig. & \multicolumn{1}{c|}{$\mathrm{t}$} & \multicolumn{1}{c|}{ df } & \multicolumn{1}{c|}{ Sig. (2-tailed) } \\
\hline Waktu & $\begin{array}{l}\text { Equal } \\
\text { variances } \\
\text { assumed }\end{array}$ & .469 & .513 & -1.660 & 8 & .135 \\
& $\begin{array}{l}\text { Equal } \\
\text { variances not } \\
\text { assumed }\end{array}$ & & & -1.660 & 7.845 & .136 \\
\hline
\end{tabular}

The results of the Normality test for one sample column Smirnov showed that the results of treatment in the form of response time for 5 rajungan samples using 2 different types of bait showed that the Natural Feed P value (0.20> $0.05)$ and Artificial Bait $P$ value (0.19>0.05) then Ho was accepted thus it can be stated that the treatment has a normally distributed value.

Independent t-test results with the basic design of RAL (Complete Random Design). Significant value 0.13> 0.05 , then Ho is accepted, it can be concluded that there is no significant time difference between rajungan in detecting chemical stimuli of natural bait and artificial bait.

Rajungan time difference in responding or detecting chemical stimulation produced by bait is shown in figure 4 , to ten samples, the time needed for natural bait is faster than artificial bait, except in sample 3 so it can be concluded that interest in chemical stimulation of natural bait is faster compared to artificial bait.

Stimulus chemical stimulation of bait makes the rajungan respond with signal perception by chemoreceptors in the antennule, mouth and prepaid will move continuously with increasing intensity

\section{Orientation}

Based on the results of observations in the feed test aquarium given in the form of natural bait and modification of the bait can cause stimulation in the rajungan, the olfactory organ which first plays a role. These organs are usually used to detect prey/bait that is located far away. These stimuli arise because of the chemical content in the bait.

The second phase is the orientation (orientation), where the animals prepare for the movement of interest or reject. The position of the crustacean changes relative to the position before stimulation, but does not move and continues to respond as in phase 1 the movements shown by the rajungan are likely to remain silent and are in the path of movement towards the bait.

Table 4. Orientation phase t-test

\begin{tabular}{|cll|l|l|r|r|}
\hline & & $F$ & Sig. & \multicolumn{1}{c|}{$t$} & df & Sig. (2-tailed) \\
\hline Waktu & $\begin{array}{l}\text { Equal } \\
\text { variances } \\
\text { assumed }\end{array}$ & 1.550 & .248 & -.084 & 8 & .935 \\
$\begin{array}{l}\text { Equal } \\
\text { variances not } \\
\text { assumed }\end{array}$ & & & -.084 & 7.044 & .935 \\
\hline
\end{tabular}

The results of the Normality test for one sample column Smirnov showed that the treatment results in the form of response time for 5 rajungan samples using 2 different types of bait showed that the Natural P-value of P (0.20> $0.05)$, and the value of Artificial Bait $P(0.053>0.05)$ then Ho thus it can be stated that the treatment has a normally dis tributed value.

Independent t-test results with the basic design of RAL (Complete Random Design). Significant value 0.93> 0.05 , then Ho is accepted, it can be concluded that there is no significant time difference in rajungan in detecting chemical stimuli of natural feeds and artificial baits.

These results indicate differences in the time of rajungan in the orientation behavior of the chemical stimuli produced by the bait. As seen in figure 12, there is no significant difference in the time required by the rajungan to orient the bait between 15-45 seconds.

\section{Locomotion}

Movement (locomotion), the rajungan begins to move slowly because it is attracted or refused. towards or away from sources of chemical signals, and occasionally continue to respond as in phase 1 and phase 2

Table 5. Locomotion phase t-test

\begin{tabular}{|c|c|c|c|c|c|c|}
\hline & & $\mathrm{F}$ & Sig. & t & df & Sig. (2-tailed) \\
\hline \multirow[t]{2}{*}{ Waktu } & $\begin{array}{l}\text { Equal } \\
\text { variances } \\
\text { assumed }\end{array}$ & .000 & .990 & -1.432 & 8 & 190 \\
\hline & $\begin{array}{l}\text { Equal } \\
\text { variances not } \\
\text { assumed }\end{array}$ & & & -1.432 & 7.612 & 192 \\
\hline
\end{tabular}

The results of the Normality test for one sample column smirnov showed that the results of treatment in the form of response time for 5 rajungan samples using 2 different 
types of bait showed that the Natural Feed P value (0.14> 0.05), and $\mathrm{P}$ Artificial Bait value (0.45>0.05) then Ho thus it can be stated that the treatment has a normally distributed value.

Independent $t$ test results with the basic design of RAL (Complete Random Design). Significant value 0.19> 0.05 , then Ho is accepted, it can be concluded that there is no significant time difference between rajungan in detecting chemical stimuli of natural bait and artificial bait.

This comparison data shows the time it takes for the rajungan to respond and move (Locomotion) in finding the bait position with a not too significant time range in the two different types of bait. Chemical stimulation of the rajungan when the rajungan-movement towards the feed (Locomotion), the organ of vision that comes into play, but not apart that the olfactory organs still come to work this thing looks jelaas antenulla occasional rajungan rajungan is still moving in a state of moving toward the bait.

\section{Initiation of Feeding}

Initiation for feeding, the rajungan begins to handle and consume food (incitant or pressing). And move up to the food source, then handle food with cheliped and mouth parts so that the chemoreceptor is exposed to chemical signals.

Table 6. Test t phase initiation offeeding

\begin{tabular}{|cll|l|l|r|r|}
\hline & & F & Sig. & t & df & Sig. (2-tailed) \\
\hline Waktu & $\begin{array}{l}\text { Equal } \\
\text { variances } \\
\text { assumed }\end{array}$ & 3.051 & .119 & -7.459 & 8 & .000 \\
& & & & & \\
\hline & $\begin{array}{l}\text { Equal } \\
\text { variances not } \\
\text { assumed }\end{array}$ & & & -7.459 & 4.172 & .001 \\
\hline
\end{tabular}

Results of the normality test for one sample column Smirnov showed that the results of treatment in the form of response time for 5 rajungan samples using 2 different types of bait showed that the natural feed $\mathrm{P}$ value (0.71> $0.05)$, and the value of Artificial Bait $P(0.13>0.05)$ then Ho thus it can be stated that the treatment has a normally distributed value.

Independent t-test results with the basic design of RAL (Complete Random Design). Significant value 0.001 $<0.05$, then Ho is rejected so it can be concluded that there are significant differences in rajungan time in initiating feeding on natural bait and artificial bait.

These results indicate differences in patterns of movement and initiation of different types of bait, in this phase the response shown by the rajungan to natural bait is to directly carry out feeding activities on fish feed as bait, while the response shown in bait modification is that the rajungan slowly approaches the bait but it did not directly initiate to eat, the rajungan circled around the bait and moved towards the back of the bait.

The rajungan behavior in responding to food based on its motion patterns is divided into 2 namely direct motion patterns and indirect motion patterns. The pattern of direct motion is the behavior of the rajungan moving towards the food area and grabbing food by following a predetermined direction of movement, while the indirect pattern of the rajungan will find food with longer movements, uneven patterns, and tend to go back and forth to the food source. The rajungan movement pattern is indicated by the direction of the arrow as follows:

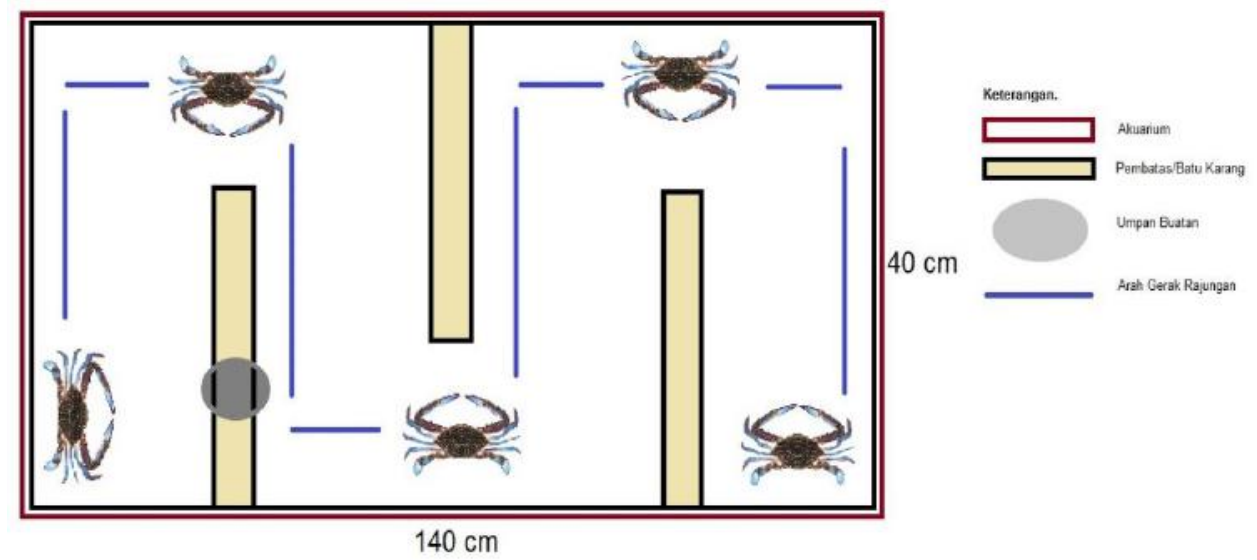

Fig.3: Artificial Bait Pattern

Observation on the use of artificial bait shows the rajungan moves slowly out of the aurosal phase towards the searching area. Then the rajungan will pause and reenter the aurosal area and stop, then the rajungan continues to search for food until it enters the last area and finds food.

In observing this artificial bait, it shows that the rajungan moves out of the start area and moves backwards to the 


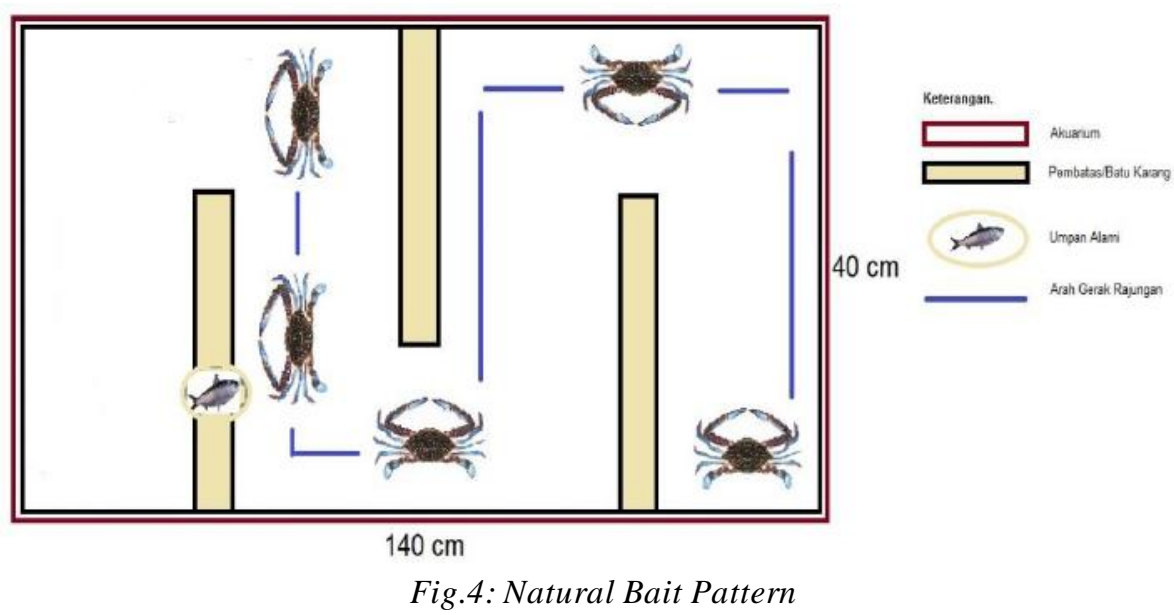

Whereas observations using natural bait show the rajungan making a direct movement towards the center of the food source in a straight pattern. The direction of this movement is behavior that tends to be shown by adult rajungan even though initially adult rajungan tend to be more silent than juvenile rajungan which shows an aggressive response to food consumption and has a movement pattern that tends to be fast (Fahresa, 2016). Other behaviors shown by adult rajungan are also due to the form of awareness of the stimulus, after making sure there is food then the new rajungan will move towards the center of the stimulus, other movement patterns also show the rajungan moving sideways in the start area then exit and stop in the second area, silent first with a faster antennule movement indicating the rajungan is observing and looking at the smell then looking at the location of the food, after confirming the location of the food the rajungan will immediately walk towards the center of food

\section{CONCLUSION}

The time ratio of rajungan in response to natural bait and artificial bait to the 4 phases of chemical stimulation shows phase detection. Significant value 0.13>0.05, indicating no significant time difference, in detecting the chemical stimulation of natural bait and artificial bait. Phase Orientation, Significant value 0.93>0.05, Indicates that there is no significant time difference in rajungan in response to chemical stimuli of natural bait and artificial bait. Locomotion phase, Significant value 0.19>0.05, Indicating no significant time difference, Phase Initiation of Feeding, Significant value $0.001<0.05$, Indicating a significant time difference, in initiating feeding on natural bait and artificial bait.

The pattern of movement that shows the rajungan on natural bait is a pattern of direct movement, the rajungan moves towards the food source by following a predetermined pattern, while the pattern of movement that shows the rajungan on artificial bait is an indirect movement pattern, the rajungan moves slowly back and forth and circulates around the food source.

\section{REFERENCES}

[1] Adam, 2006 Numerical Model of Diffusion of Rajungan Populations in the Makassar Strait Waters. Blue Swimming Rajungan Fisheries Research Journal

[2] Fitri, ADP 2009. Vision and Smelling Response of the Fish of the Tiger ( Ephinephelus fuscoguttatu s) against Artificial Bait. Journal of Fisheries at Diponegoro University. Semarang.

[3] Miller, RJ 1990. Option for reducing bycatch in lobster and rajungan pots. Proceedings of the International Symposium on Biology and Economics of Rajungan from High Latitude Habits . Anchorage, Alaska, USA; p. 163168

[4] Natsir, M. 2003. Research Methods . Ghalia Indonesia, Jakarta.

[5] Rakhmadevi, CC2004. The resting time and month period against the rajungan caught by the traps are in the Pontianak Radak river. Faculty of Fisheries and Marine Science. IPB: Bogor

[6] Ramdani, D. 2007. Comparison of Catches of Rajungan on Folded Traps by Using Different Bait (thesis). Bogor Faculty of Fisheries, Bogor Agriculture Institute, 73 p.

[7] Subani, W. and HR Barus. 1989. Fishing equipment for sea and shrimp in Indonesia. Journal of 50 Marine Fisheries Research (Special Edition). Fisheries Research Institute Agricultural Research and Development Agency Ministry of Agriculture, Jakarta.

[8] Supadminingsih, Fahresa Nugraheni. 2015. Behavior Analysis of Mangrove Rajungan on Feeds and Age Structures of Different Laboratory Scales. Utilization of Fisheries Resources 4 (3): 57-61 